\title{
AKUMULASI LOGAM BERAT Pb, Cd, Ni DAN Zn PADA DAGING IKAN DI TELUK KAO, HALMAHERA
}

\section{ACCUMULATION OF HEAVY METALS Pb, Cd, Ni AND Zn ON FISH MEAT IN KAO, HALMAHERA}

\author{
Edward \\ ${ }^{1}$ Pusat Penelitian Oseanografi-LIPI \\ Jl. Pasir Putih I, Ancol Timur, Jakarta Utara \\ E-mail: ekewe07@gmail.com
}

(Diterima: 26 Juli 2019; Diterima setelah perbaikan: 1 September 2019; Disetujui: 1 September 2019)

\begin{abstract}
ABSTRAK
Ikan merupakan sumber protein, mineral, vitamin dan asam lemak omega-3-tidak jenuh (poly unsaturated), yang dianggap bermanfaat bagi kesehatan. Tujuan penelitian in adalah untuk mengetahui tingkat akumulasi logam berat timbal $(\mathrm{Pb})$, cadmium $(\mathrm{Cd})$, seng $(\mathrm{Zn})$ dan nikel $(\mathrm{Ni})$ pada beberapa jenis ikan yang berbeda di Teluk Kao, Halmahera. Penelitian ini dilakuan pada bulan November 2015. Contoh ikan yang dianalisis adalah ikan suo (Sphyraena jello), tatameri (Gazza minuta), gaca (Lutjanus argentimaculatus), totodi (Synodus foetens) bubara (Caranx sp), ngafi (Stolephorus indicus) dan biji nangka (Upeneus vittatus). Kadar $\mathrm{Pb}, \mathrm{Cd}, \mathrm{Zn}$ dan $\mathrm{Ni}$ ditentukan dengan alat Spektrofotometer Serapan Atom (AAS). Hasilnya menunjukkan kadar $\mathrm{Pb}, \mathrm{Cd}$, Zn dan $\mathrm{Ni}$ masih sesuai dengan nilai ambang batas aman yang ditetapkan oleh Standard Nasional Indonesia (SNI) 2009. Untuk mengoptimalkan perlindungan terhadap kesehatan manusia, perlu dilakukan pemantauan kadar $\mathrm{Pb}, \mathrm{Cd}, \mathrm{Zn}$ dan Ni dalam daging ikan yang hidup di Teluk Kao, mengingat Teluk Kao merupakan satu-satunya perairan yang menerima masukan limbah yang berasal dari kegiatan masyarakat dan penambangan emas. Strategi manajemen risiko harus fokus pada pengurangan paparan potensial yang berasal dari konsumsi ikan.
\end{abstract}

KATA KUNCI: Teluk Kao; ikan; logam berat; akumulasi

\begin{abstract}
Fish is a source of protein, minerals, vitamins and omega-3-not saturated (poly unsaturated) fatty acids, which are considered beneficial for health. The purpose of this study was to determine the level of accumulation of heavy metals lead $(\mathrm{Pb})$, cadmium $(\mathrm{Cd})$, zinc $(\mathrm{Zn})$ and nickel $(\mathrm{Ni})$ in several different fish species in Kao Bay, Halmahera. This research was carried out in November 2015. Fish samples analyzed were suo (Sphyraena jello), tatameri (Gazza minuta), gaca (Lutjanus argentimaculatus), totodi (Synodus foetens) bubara (Caranx sp), ngafi (Stolephorus indicus) and biji nangka (Upeneus vittatus). $\mathrm{Pb}, \mathrm{Cd}, \mathrm{Zn}$ and $\mathrm{Ni}$ levels were determined by Atomic Absorption Spectrophotometer (AAS). The results showed the levels of $\mathrm{Pb}, \mathrm{Cd}, \mathrm{Zn}$ and $\mathrm{Ni}$ are still in accordance with the safe threshold values set by the 2009 Indonesian National Standard (SNI). To optimize the protection of human health, it is necessary to monitor the levels of $\mathrm{Pb}, \mathrm{Cd}$, $\mathrm{Zn}$ and $\mathrm{Ni}$ in fish meat live in Kao Bay, considering that Kao Bay is the only water that receives waste inputs from community activities and gold mining. The risk management strategy must focus on reducing potential exposure from fish consumption.
\end{abstract}

KEYWORDS: Teluk Kao; fish; heavy metals; accumulation

\section{PENDAHULUAN}

Teluk Kao (Halmahera) merupakan salah satu lokasi penangkapan ikan bagi nelayan untuk memenuhi

\# Korespondensi: Pusat Penelitian Oseanografi

E-mail: ekewe07@gmail.com kebutuhan protein hewani. Teluk ini kaya akan sumberdaya ikan seperti kepiting kenari, cumi-cumi, mutiara, ubur-ubur, ikan teri, udang dan sebagainya. Kehadiran penambangan emas di daratan Kao sejak tahun 1997, telah menimbulkan masalah terhadap lingkungan, selain membawa pengaruh yang positif 
pada masyarakat yang bermukim di Kecamatan Kao, khususnya pada sektor ekonomi, pendidikan, dan kesehatan, juga membawa pengaruh negatif yakni berupa pencemaran. Pencemaran terjadi akibat limbah tambang yang masuk ke Teluk Kao. Limbah ini mengandung berbagai bahan kimia yang berbahaya, diantaranya adalah logam berat (Edward, 2017).

Beberapa dari logam berat bersifat racun terhadap organisme akuatik bahkan pada konsentrasi yang sangat rendah sekalipun, sedangkan yang lain penting secara biologis namun menjadi racun pada konsentrasi yang relatif tinggi (Duruibe et al., 2007). Logam berat akan terakumulasi dalam jaringan ikan dan melalui rantai makanan dapat mempengaruhi kesehatan manusia, karena itu penting untuk mengetahui kadar logam berat pada daging ikan dan sehingga tidak berbahaya bagi kesehatan manusia.

Ikan merupakan organisme air yang dapat bergerak dengan cepat. Ikan pada umumnya mempunyai kemampuan menghindarkan diri dari pengaruh pencemaran air. Namun demikian, pada ikan yang hidup dalam habitat yang terbatas (seperti sungai, danau dan teluk), ikan itu sulit melarikan diri dari pengaruh pencemaran tersebut. Akibatnya, unsur-unsur pencemaran itu masuk ke dalam tubuh ikan. Secara umum, logam berat masuk ke dalam jaringan tubuh makhluk hidup melalui beberapa jalan, yaitu saluran pernafasan, pencernaan, dan penetrasi melalui kulit. Di dalam tubuh hewan, logam diabsorpsi oleh darah, berikatan dengan protein darah yang kemudian didistribusikan ke seluruh jaringan tubuh. Akumulasi logam yang tertinggi biasanya dalam detoksikasi (hati) dan ekskresi (ginjal) (Suyanto et al., 2010).
Beberapa hasil penelitian menunjukkan adanya akumluasi logam berat dalam ikan. Misalnya Purnomo et al., (2016) melaporkan adanya akumulasi $\mathrm{Pb}$ pada Ikan Bandeng (Chanos chanos Forsk.) yang dipelihara di Tambak Kecamatan Gresik, Hidayah et al., (2014) melaporkan adanya akumulasi Cd pada ikan Nila (Oreochromis niloticus Linn.) yang dibudidayakan di Danau di Rawabening dan Lihan et al., (2006) melaporkan kadar Ni pada 10 jenis ikan laut di Tanjung Karang, selanjutnya Suyanto et al., (2010) melaporkan adanya akumulasi Zn pada ikan yang dipelihara di tambak-tambak di Pati, Semarang dan Tegal.

Penelitian ini bertujuan untuk mengetahui akumulasi logam berat $\mathrm{Pb}, \mathrm{Cd}, \mathrm{Zn}$ dan $\mathrm{Ni}$ pada beberapa jenis ikan yang berbeda yang hidup di Teluk Kao. Metode penelitian yang digunakan adalah metode survey, dimana pengambilan contoh langsung dilakukan di lapangan. Hasil penelitian ini diharapkan dapat memberikan informasi kepada pemda dan masyarakat setempat tentang kesehatan makanan hasil laut yang berasal dari Teluk Kao, sehingga dampak negatif yang mungkin timbul akibat mengkonsumsi makanan hasil laut yang berasal dari Teluk dapat diantisipasi sedini mungkin.

\section{BAHAN DAN METODE}

Penelitian ini dilakukan pada bulan November 2015 di perairan Teluk Kao, Pulau Halmahera, Maluku Utara. Contoh ikan dibeli dan diambil di Teluk Kao (Gambar 1), disimpan dalam ice box pada suhu $4^{\circ} \mathrm{C}$, selanjutnya dibekukan dalam lemari pendingan dan dibawa ke laboratorium Pusat Penelitian Oseanografi-LIPI Jakarta. Di laboratorium contoh ikan dipisahkan masingmasing 3 ekor dengan ukuran yang relatif sama, diukur panjang dan ditimbang beratnya, kemudian dicatat panjang dan berat rerata dari masing-masing ikan.

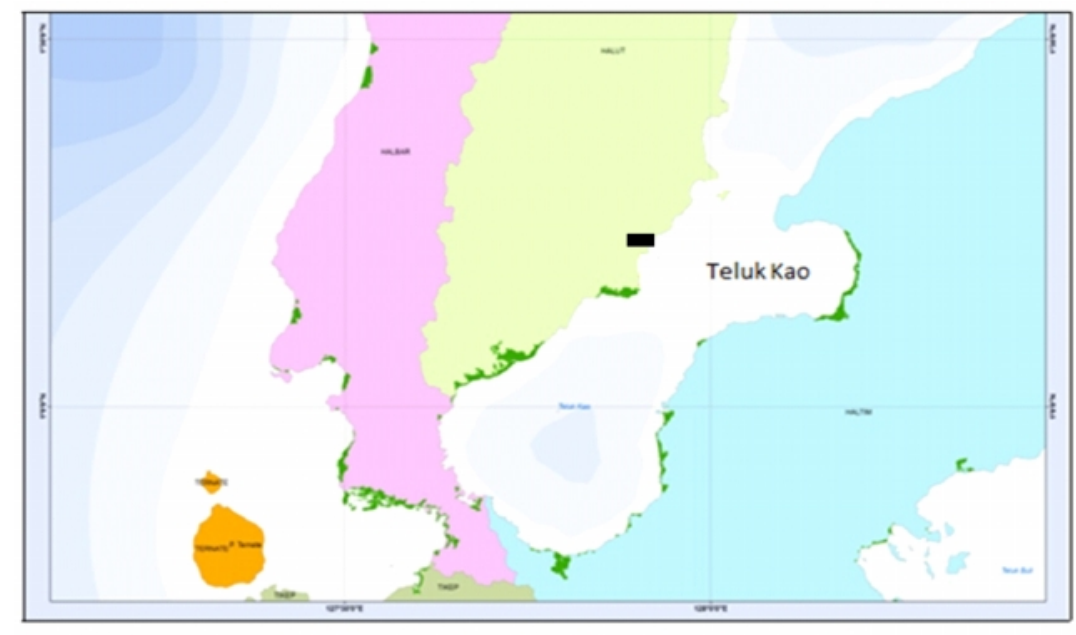

: Desa Malifud (Lokasi pembelian dan pengambilan contoh)

Gambar 1. Lokasi Penelitian (Teluk Kao, Halmahera).

Figure 1. Map of Research Location (Kao Bay, Halmahera). 
Selanjutnya contoh ditimbang secara analitis sebanyak 5 gram, dimasukkan dalam cawan teflon, didestruksi dengan menggunakan $\mathrm{HNO}_{3} / \mathrm{HCl}$ pekat dan biarkan pada suhu ruang $\pm 4 \mathrm{jam}$. Destruksi dilanjutkan pada suhu $90^{\circ} \mathrm{C}$ selama 8 jam dan disaring. Kadar $\mathrm{Pb}, \mathrm{Cd}$, Zn dan Ni ditentukan dengan AAS Varian SpectrAA20 Plus menggunakan nyala campuran udara-asetilen (Hutagalung et al., 1997). Kadar dinyatakan dalam ppm ( $\mathrm{mg} / \mathrm{kg}$, berat basah).

Analisis data dilakukan secara deskriptif dengan membandingkannya dengan hasil penelitian lain dan dengan kriteria yang ditetapkan untuk kesehatan makanan yang berasal dari laut.

Batas maksimum kadar logam berat yang terakumulasi dalam contoh yang diperbolehkan dikonsumsi per minggu (Maximum Weekly Intake) ditentukan dengan menggunakan nilai ambang batas yang ditetapkan oleh US National Research Council (Kuras et al., 2017), WHO/ FAO dan JEFCA (Peycheva et al., 2016).

Asupan maksimum per minggu (Maximum Weekly Intake) dihitung dengan menggunakan rumus:

$$
\operatorname{MWI}(\mathrm{g})=\text { Berat Badan }^{\text {a) }} \mathrm{x} \text { PTWI }{ }^{\text {b) }}
$$

\section{Keterangan:}

a) Rerata berat badan orang dewasa Indonesia $50 \mathrm{~kg}$ (Kemenkes RI, 2010 dalam Cahyani et al., 2016) dan anak-anak adalah $15 \mathrm{~kg}$

b) PTWI (Provisional Tolerable Weekly Intake) atau asupan yang diperkenakan per minggu dalam satuan $\mu \mathrm{g} / \mathrm{kg}$ berat badan (Tabel 2 )

Batas maksimum berat daging ikan dan kerang yang dapat ditolerir untuk dikonsumsi dalam waktu satu minggu (Maximum Tolerable Intake, MTI) dihitung dengan menggunakan rumus sebagi berikut (Turkmen et al., 2008):

\section{$\mathrm{MTI}=\mathrm{MWI} / \mathrm{Ct}$}

\section{Keterangan:}

MWI = Maximum Weekly Intake (mg untuk berat badan orang dewasa Indonesia $50 \mathrm{~kg}$ dan anak-anak $15 \mathrm{~kg}$ per minggu). $\mathrm{Ct}=$ Konsentrasi logam berat yang ditemukan di dalam daging ikan (ppm atau mg/ kg) (Cahyani et al., 2016).

Tabel 1. Contoh ikan dan kerang yang berasal dari Teluk Kao

Table 1. Fishes and Shells Sample from Kao Bay

\begin{tabular}{lcc}
\hline \multicolumn{1}{c}{ Nama Ikan } & Panjang Rerata cm $(\mathrm{N}=3)$ & Berat gr (Rerata) \\
\hline Suo (Sphyraena jello) & 25,5 & 97,092 \\
Gaca (Lutjanus argentimaculatus) & 24,3 & 187,550 \\
Totodi (Synodus foetens) & 25,4 & 124,446 \\
Gurara (Nemipterus japonicus) & 17,3 & 87,612 \\
Biji Nangka (Upeneus vittatus) & 19,2 & 86,170 \\
Ngafi (Stolephorus indicus) & 8,9 & 11,991 \\
Tatameri (Gazza minuta) & 17,2 & 88,342 \\
Bubara (Caranx sp) & 24,2 & 147,732 \\
\hline
\end{tabular}

Tabel 2. Asupan yang diperkenankan per minggu

Table 2. Provisional tolerable weekly intake

\begin{tabular}{ccc}
\hline Jenis Logam & PTWI $(\mu \mathrm{g} / \mathrm{kg}$ berat badan $)$ & Referensi \\
per minggu & \\
\hline $\mathrm{Pb}$ & 25 & Cahyani et al., (2016) \\
$\mathrm{Cd}$ & 7 & Cahyani et al., (2016) \\
$\mathrm{Zn}$ & 7000 & Peycheva et al., (2016) \\
$\mathrm{Ni}$ & 35 & Peycheva et al., (2016) \\
\hline
\end{tabular}

\section{HASIL DAN PEMBAHASAN}

\section{Hasil}

Hasil pengukuran kadar $\mathrm{Pb}, \mathrm{Cd}, \mathrm{Zn}$ dan $\mathrm{Ni}$ dalam beberapa jenis ikan di Teluk Kao disajikan pada Tabel 3. Dari tabel tersebut dapat dilihat kadar Pb tertinggi dijumpai pada ikan Totodi (Synodus foetens) dan terendah pada ikan suo (Sphyraena jello) dan
Bubara(Caranx sp) dan ikan Suo (Sphyraena jello). Kadar Cd tertinggi dijumpai pada Totodi (Synodus foetens) dan terendah pada Ngafi (Stolephorus indicus), dan kadar Zn tertinggi dijumpai pada Totodi (Synodus foetens) dan terendah pada ikan tatameri (Gazza minuta), kadar Ni tertinggi dijumpai pada ikan tatameri (Gazza minuta) dan terendah pada ikan ikan gaca (Lutjanus argentimaculatus). Data di atas menunjukkan 
kadar logam berat $\mathrm{Pb}, \mathrm{Cd}, \mathrm{Zn}$ dan $\mathrm{Ni}$ bervariasi pada setiap jenis ikan.

\section{Pembahasan}

\section{Plumbum (Pb)}

Logam $\mathrm{Pb}$ merupakan logam non esensial yang belum diketahui kegunaannya dalam tubuh makhluk hidup, sehingga keberadaannya lebih dari kadar normal dapat menyebabkan keracunan. Keberada an logam $\mathrm{Pb}$ dalam tubuh seringkali menggantikan logam esensial dalam aktivitas kerja enzim dan bersifat menghambat kerja enzim (Purnomo et al., 2016). (Palar, 2004 dalam Hidayah et al., 2014).
Dari Tabel 3 di atas dapat dilihat kadar $\mathrm{Pb}$ dalam setiap jenis ikan berbeda. Kadar $\mathrm{Pb}$ tertinggi dijumpai pada daging Totodi (Synodus foetens) yakni 0,49 ppm dan terendah pada daging ikan suo (Sphyraena jello) dan Bubara (Caranx sp) yang kadarnya masing-masing adalah 0,08 ppm. Data di atas menunjukkan bahwa Totodi (Synodus foetens) mengakumulasi Pb lebih banyak dibandingkan dengan yang lainnya. Data di atas juga menunjukkan kadar $\mathrm{Pb}$ pada ikan terlihat bervariasi sesuai dengan jenisnya.

Kadar $\mathrm{Pb}$ ini masih lebih rendah dibandingkan dengan nilai ambang batas yang aman untuk makanan hasil laut yang ditetapkan beberapa negara, kecuali European Commission, FAO dan SNI relatif lebih tinggi (Tabel 4).

Tabel 3. Rerata kadar $\mathrm{Pb}, \mathrm{Cd}$, Zn dan Ni dalam daging ikan di Teluk Kao

Table 3. Avarage concentration of $\mathrm{Pb}, \mathrm{Cd}, \mathrm{Zn}$ and $\mathrm{Ni}$ in fish meat in Kao Bay

\begin{tabular}{ccccc}
\hline Biota Laut & \multicolumn{3}{c}{ Kadar, ppm } \\
\hline Ikan & $\mathrm{Pb}$ & $\mathrm{Cd}$ & $\mathrm{Zn}$ & $\mathrm{Ni}$ \\
\hline Suo (Sphyraena jello) & 0,08 & 0,13 & 21,37 & 0,33 \\
Gaca (Lutjanus argentimaculatus) & 0,28 & 0,19 & 41,84 & 0,28 \\
Totodi (Synodus foetens) & 0,49 & 0,36 & 42,55 & 0,60 \\
Gurara (Nemipterus japonicus) & 0,09 & 0,22 & 16,0 & 0,47 \\
Biji Nangka (Upeneus vittatus) & 0,28 & 0,15 & 14,64 & 0,83 \\
Ngafi (Stolephorus indicus) & 0,09 & 0,07 & 31,79 & 0,81 \\
Tatameri (Gazza minuta) & 0,28 & 0,15 & 13,76 & 1,18 \\
Bubara(Caranx sp) & 0,08 & 0,18 & 16,00 & 1,13 \\
\hline
\end{tabular}

Tabel 4. Perbandingan kadar Pb pada Ikan di Teluk Kao dengan kriteria dari beberapa negara

Table 4. Comparison of $\mathrm{Pb}$ concentrations in fish in Kao Bay with criteria from several countries

\begin{tabular}{lc}
\hline \multicolumn{1}{c}{ Jenis } & Kadar,ppm \\
\hline Suo (Sphyraena jello) & 0,08 \\
Gaca (Lutjanus argentimaculatus) & 0,28 \\
Totodi (Synodus foetens) & 0,49 \\
Gurara (Nemipterus japonicus) & 0,09 \\
Biji Nangka (Upeneus vittatus) & 0,28 \\
Ngafi (Stolephorus indicus) & 0,09 \\
Tatameri (Gazza minuta) & 0,28 \\
Bubara(Caranx sp) & 0,08 \\
\hline Nilai Ambang Batas & $0,20-0,40$ \\
\hline EuropeanCommission (2001)* & 0,5 \\
USFDA (1993)* & 2,0 \\
WHO (1985)* & 0,20 \\
FAO (2003)* & 2 \\
MFA (1993)* & $0,3-0,4$ \\
SNI (2009) & \\
\hline
\end{tabular}

Hasil perhitungan Maximum Weekly Intake untuk $\mathrm{Pb}$ disajikan pada Tabel 5. Maximum Weekly Intake adalah asupan maksimum kontaminan logam berat yang diperboleh masuk ke tubuh selama satu minggu. Dari tabel tersebut dapat dilihat kadar Pb maksimum yang diperbolehkan dikonsumsi untuk orang dewasa dengan berat $50 \mathrm{~kg}$ adalah $1,250 \mathrm{mg}$.
Kadar tertinggi $\mathrm{Pb}$ dijumpai pada ikan Totodi (Synodus foetens) yakni 0,49 ppm atau $0,49 \mathrm{mg} / \mathrm{kg}$, artinya dalam $1 \mathrm{~kg}$ daging ikan Totodi (Synodus foetens) terdapat $0,49 \mathrm{mg} \mathrm{Pb}$.

Febrianto (2018) menyatakan konsumsi ikan orang dewasa Indonesia per orang per tahun adalah 47 
$\mathrm{kg}(0,979 \mathrm{~kg}$ per minggu). Maka asupan Pb per minggu ke dalam tubuh adalah $(0,979: 1) \times 0,49 \mathrm{mg}=0,479 \mathrm{mg}$. Kadar ini lebih rendah dari asupan maksimum per minggu (MWI) Pb untuk orang dewasa dengan berat badan $50 \mathrm{~kg}$ per minggu yakni 1,250 mg. Nilai MTI (maximum Tolerable Intake) didapat dengan membagi nilai MWI $(1,250) \mathrm{mg}$ dengan kadar $\mathrm{Pb}$ yang terdapat dalam $1 \mathrm{~kg}$ ikan yakni 0,49 mg sebagai berikut: $(1,250$ : 0,49$) \times 1 \mathrm{~kg}=2,551 \mathrm{~kg}$ atau $2551 \mathrm{~g}$ per minggu untuk orang dengan berat badan $50 \mathrm{~kg}$.

Dengan cara yang sama diperoleh nilai MTI untuk ikan yang lain (Tabel 6). Dengan demikian bila orang dewasa dengan berat badan rerata $50 \mathrm{~kg}$ mengkonsumsi daging ikan sesuai dengan nilai MTI nya, maka belum berbahaya bagi kesehatan tubuh.

Dari Tabel 5 di atas dapat dilihat kadar $\mathrm{Pb}$ maksimum yang diperbolehkan dikonsumsi untuk anak dengan berat badan $15 \mathrm{~kg}$ adalah $0,375 \mathrm{mg}$. Kadar tertinggi $\mathrm{Pb}$ dijumpai pada ikan Totodi (Synodus foetens) yakni $0,49 \mathrm{ppm}$ atau $0,49 \mathrm{mg} / \mathrm{kg}$, artinya dalam $1 \mathrm{~kg}$ daging ikan Totodi (Synodus foetens) terdapat 0,49 $\mathrm{mg} \mathrm{Pb}$.

Bila konsumsi ikan anak-anak dengan berat badan $15 \mathrm{~kg}$ rerata per minggu sepertiganya orang dewasa yakni $0,326 \mathrm{~kg}$, maka asupan $\mathrm{Pb}$ nya ke dalam tubuh adalah $(0,326: 1) \times 0,49 \mathrm{mg}=0,159 \mathrm{mg}$. Kadar ini lebih rendah dari $\mathrm{MWI} \mathrm{Pb}$ untuk anak-anak dengan berat badan $15 \mathrm{~kg}$ per minggu yakni 0,375 mg.

Nilai MTI (maximum Tolerable Intake) didapat dengan membagi nilai MWI $(0,375) \mathrm{mg}$ dengan kadar $\mathrm{Pb}$ yang terdapat dalam $1 \mathrm{~kg}$ ikan yakni $0,49 \mathrm{mg}$ sebagai berikut: $(0,375: 0,49) \times 1 \mathrm{~kg}=0,765 \mathrm{~kg}$ atau $765 \mathrm{~g}$ per minggu untuk orang dengan berat badan 15 $\mathrm{kg}$. Dengan cara yang sama diperoleh nilai MTI untuk ikan yang lain (Tabel 7).

Tabel 5. Asupan maksimum $\mathrm{Pb}$ yang diperkenankan per minggu

Table 5. Tolerable maximum weekly intake of $\mathrm{Pb}$

\begin{tabular}{ccc}
\hline $\begin{array}{c}\text { Jenis } \\
\text { Logam }\end{array}$ & $\begin{array}{c}\text { PTWI }(\mu \mathrm{g} / \mathrm{kg} \mathrm{b.b}) \text { per } \\
\text { minggu* }\end{array}$ & MWI (orang dewasa, $50 \mathrm{~kg})$ per Minggu \\
\hline $\mathrm{Pb}$ & 25 & $1,250 \mathrm{mg}$ \\
& & MWI (anak-anak, $15 \mathrm{~kg})$ per Minggu \\
$\mathrm{Pb}$ & 25 & $0,375 \mathrm{mg}$ \\
\hline
\end{tabular}

*Cahyani et al. (2016)

Tabel 6. Asupan maksimum $\mathrm{Pb}$ yang diperkenankan per minggu untuk dewasa dengan berata badan $50 \mathrm{~kg}$ Table 6. Tolerable maximum weekly intake of $\mathrm{Pb}$ for adults with $50 \mathrm{~kg}$ body weight

\begin{tabular}{lcc}
\hline \multicolumn{1}{c}{ Jenis Ikan } & $\mathrm{Pb}, \mathrm{mg} / \mathrm{kg}=\mathrm{Ct}$ & $\mathrm{MTI}=\mathrm{MWI} / \mathrm{Ct}(\mathrm{g}), \mathrm{MWI}$ Pb: 1,250 mg \\
\hline Suo (Sphyraena jello) & 0,08 & 15625 \\
Kaca (Lutjanus argentimaculatus) & 0,28 & 4467 \\
Totodi (Synodus foetens) & 0,49 & 2551 \\
Gurara (Nemipterus japonicus) & 0,09 & 13888 \\
Biji Nangka (Upeneus vittatus) & 0,28 & 4464 \\
Ngafi (Stolephorus indicus) & 0,09 & 13888 \\
Tatameri (Gazza minuta) & 0,28 & 4464 \\
Bubara(Caranx sp) & 0,08 & 15625 \\
\hline
\end{tabular}

Tabel 7. Asupan maksimum Pb yang diperkenankan per minggu untuk anak dengan berat badan $15 \mathrm{~kg}$ Table 7. Tolerable maximum weekly intake of $\mathrm{Pb}$ for children with $15 \mathrm{~kg}$ body weight

\begin{tabular}{lcc}
\hline \multicolumn{1}{c}{ Jenis Ikan } & $\mathrm{Pb}, \mathrm{mg} / \mathrm{kg}=\mathrm{Ct}$ & $\mathrm{MTI}=\mathrm{MWI} / \mathrm{Ct}(\mathrm{g}), \mathrm{MWI} \mathrm{Pb}: 0,375 \mathrm{mg}$ \\
\hline Suo (Sphyraena jello) & 0,08 & 4687 \\
Kaca (Lutjanus argentimaculatus) & 0,28 & 1339 \\
Totodi (Synodus foetens) & 0,49 & 765 \\
Gurara (Nemipterus japonicus) & 0,09 & 4166 \\
Biji Nangka (Upeneus vittatus) & 0,28 & 1339 \\
Ngafi (Stolephorus indicus) & 0,09 & 4166 \\
Tatameri (Gazza minuta) & 0,28 & 1339 \\
Bubara(Caranx $\mathrm{sp}$ ) & 0,08 & 4687 \\
\hline
\end{tabular}


Dengan demikian bila anak dengan berat badan rerata $15 \mathrm{~kg}$ mengkonsumsi daging ikan di atas sesuai dengan nilai MTI nya, maka belum berbahaya bagi kesehatan tubuh.

\section{Kadmium (Cd)}

Kadmium (Cd) merupakan logam kebiruan yang lunak dan merupakan racun bagi tubuh manusia. $\mathrm{Cd}$ lebih mudah diakumulasi oleh tanaman. Cd yang terdapat dalam tubuh manusia sebagian besar diperoleh melalui saluran pernapasan dan pencernaan dan dapat terakumulasi pada ginjal sehingga ginjal mengalami disfungsi. Sumber kontaminasi Cd di lingkungan akibat aktivitas manusia yaitu penggunaan bahan bakar, kebakaran hutan, limbah industri serta penggunaan pupuk dan pestisida (Agustina, 2010; Widaningrum, et al., 2007; Dewi, 2011).

Keberadaan cadmium di lingkungan relatif kecil, namun pengaruh nya terhadap kehidupan sangat buruk, yang dapat menyebabkan keracunan akut dan kronik. Cadmium dapat beraksi dengan ligan-ligan dalam tubuh yang akan memperhambat atau mengganggu kerja enzim atau bahkan dapat dilepaskan oleh ligan sehingga terakumulasi dalam tubuh

Dari Tabel 3 di atas dapat dilihat kadar Cd dalam daging ikan berkisar 0,07-0,36 ppm dengan rerata $0,181 \mathrm{ppm}$. Kadar tertinggi dijumpai dalam daging ikan Totodi (Synodus foetens) yakni 0,36 ppm dan terendah dalam daging ikan Ngafi (Stolephorus indicus) yakni 0,07 ppm. Data ini menunjukkan bahwa ikan Totodi
(Synodus foetens) mengakumulasi Cd lebih banyak dibandingkan dengan ikan lainnya. Kadar Cd ini juga bervariasi dalam setiap jenis ikan. Kadar Cd pada ikan di Teluk Kao ini relatif lebih rendah dari nilai ambang batas untuk makanan hasil laut yang tetapkan oleh WHO, Malaysia dan SNI, namun lebih tinggi dibanding kan dengan kriteria yang ditetapkan oleh EC dan FAO (Tabel 8).

Hasil perhitungan Maximum Weekly Intake untuk Cd disajikan pada Tabel 9. Dari tabel tersebut dapat dilihat kadar Cd maksimum yang diperbolehkan dikonsumsi untuk orang dewasa dengan berat $50 \mathrm{~kg}$ adalah $0,350 \mathrm{mg}$.

Kadar tertinggi Cd dijumpai pada ikan Totodi (Synodus foetens) yakni $0,36 \mathrm{ppm}$ atau $0,36 \mathrm{mg} / \mathrm{kg}$, artinya dalam $1 \mathrm{~kg}$ daging ikan Totodi (Synodus foetens) terdapat $0,36 \mathrm{mg} \mathrm{Cd}$. Konsumsi ikan orang dewasa Indonesia per orang per tahun adalah $47 \mathrm{~kg}$ $(0,979 \mathrm{~kg}$ per minggu) dengan berat badan, misalnya untuk Indonesia rerata $50 \mathrm{~kg}$. Maka asupan $\mathrm{Cd}$ per minggu ke dalam tubuh adalah $(0,979: 1) \times 0,36 \mathrm{mg}=$ 0,352 mg. Kadar ini lebih tinggi dari MWI Cd untuk orang dewasa dengan berat badan $50 \mathrm{~kg}$ per minggu yakni $0,350 \mathrm{mg}$. Nilai $0,350 \mathrm{mg}$ ini hanya akan tercapai apabila orang memakan daging ikan Totodi sebanyak $(0,350: 0,36) \times 1 \mathrm{~kg}=0,972 \mathrm{~kg}$ atau $972 \mathrm{~g}$ per minggu untuk orang dengan berat badan $50 \mathrm{~kg}$. Dengan cara yang sama diperoleh nilai MTI untuk masing-masing ikan (Tabel 10).

Tabel 8. Perbandingan Kadar Cd dalam daging Ikan dengan kriteria dari beberapa negara

Table 8. Comparison of Cd concentration in meat fish in Kao Bay with criteria from several countries

\begin{tabular}{lc}
\multicolumn{1}{c}{ Lokasi } & $\mathrm{Cd}, \mathrm{ppm}$ \\
\hline Suo (Sphyraena jello) & 0,13 \\
Gaca (Lutjanus argentimaculatus) & 0,19 \\
Totodi (Synodus foetens) & 0,36 \\
Gurara (Nemipterus japonicus) & 0,22 \\
Biji Nangka (Upeneus vittatus) & 0,15 \\
Ngafi (Stolephorus indicus) & 0,07 \\
Tatameri (Gazza minuta) & 0,15 \\
Bubara(Caranx sp) & 0,18 \\
\hline \multicolumn{1}{c}{ Nilai Ambang Batas } \\
EC (2001)* \\
WHO (1985)* & $0,05-0,10$ \\
FAO (2003)* & 2 \\
MFA (1993)* & 0,05 \\
SNI (2009) & 1 \\
\hline Ket : & $0,1-0,5$ \\
\hline
\end{tabular}

Ket : * Hasyim et al., (2014) 
Tabel 9. Asupan maksimum Cd yang diperkenankan per minggu

Table 9. Tolerable maximum weekly intake of $\mathrm{Cd}$

\begin{tabular}{ccc}
\hline Jenis Logam & PTW I $(\mu \mathrm{g} / \mathrm{kg}$ b.b) per minggu* & MW I (orang dewasa, 50 kg) per Minggu \\
\hline Cd & 7 & $0,350 \mathrm{mg}$ \\
$\mathrm{Cd}$ & 7 & M W I (anak-anak, $15 \mathrm{~kg})$ per Minggu \\
\end{tabular}

Tabel 10. Asupan maksimum Cd yang diperkenakan per minggu untuk orang dewasa dengan Berat badan $50 \mathrm{~kg}$ Table 10. Tolerable maximum weekly intake of Cd for adults with $50 \mathrm{~kg}$ body weight

\begin{tabular}{lcc}
\hline \multicolumn{1}{c}{ Jenis Ikan } & $\mathrm{Cd}, \mathrm{mg} / \mathrm{kg}=\mathrm{Ct}$ & $\mathrm{MTI}=\mathrm{MWI} / \mathrm{Ct}(\mathrm{g})$, MWI Cd: 0,350 mg \\
\hline Suo (Sphyraena jello) & 0,13 & 2692 \\
Kaca (Lutjanus argentimaculatus) & 0,19 & 1842 \\
Totodi (Synodus foetens) & 0,36 & 972 \\
Gurara (Nemipterus japonicus) & 0,22 & 1590 \\
Biji Nangka (Upeneus vittatus) & 0,15 & 2333 \\
Ngafi (Stolephorus indicus) & 0,07 & 5000 \\
Tatameri (Gazza minuta) & 0,15 & 2333 \\
Bubara(Caranx sp) & 0,18 & 1944 \\
\hline
\end{tabular}

Tabel 11. Asupan maksimum Cd per minggu yang diperkenankan untuk anak dengan berat badan $15 \mathrm{~kg}$ Table 11. Tolerable maximum weekly intake of $\mathrm{Pb}$ for children with $15 \mathrm{~kg}$ body weight

\begin{tabular}{lcc}
\hline \multicolumn{1}{c}{ Jenis Ikan } & $\mathrm{Cd}, \mathrm{mg} / \mathrm{kg}=\mathrm{Ct}$ & $\mathrm{MTI}=\mathrm{MWI} / \mathrm{Ct}(\mathrm{g})$, MWI Cd: 0,105 mg \\
\hline Suo (Sphyraena jello) & 0,13 & 807 \\
Kaca (Lutjanus argentimaculatus) & 0,19 & 552 \\
Totodi (Synodus foetens) & 0,36 & 291 \\
Gurara (Nemipterus japonicus) & 0,22 & 477 \\
Biji Nangka (Upeneus vittatus) & 0,15 & 700 \\
Ngafi (Stolephorus indicus) & 0,07 & 1500 \\
Tatameri (Gazza minuta) & 0,15 & 700 \\
Bubara(Caranx sp) & 0,18 & 583 \\
\hline
\end{tabular}

Dengan demikian bila orang dewasa dengan berat badan rerata $50 \mathrm{~kg}$ mengkonsumsi daging ikan di atas sesuai dengan nilai MTI nya, maka belum berbahaya bagi kesehatan tubuh.

Konsumsi ikan anak dengan berat badan $15 \mathrm{~kg}$ per minggu adalah $0,326 \mathrm{~kg}$, maka asupan $\mathrm{Cd}$ ke tubuhnya adalah $(0,326: 1) \times 0,36 \mathrm{mg}=0,117 \mathrm{mg}$. Kadar ini lebih tinggi dari kadar maksimum yang diperkenankan yakni 0,105 mg. Kadar 0,105 ini akan diperoleh bila anak mengkonsumsi ikan Totodi sebanyak $(0,105: 0,36) \mathrm{x}$ $1 \mathrm{~kg}=0,291 \mathrm{~kg}$ atau $291 \mathrm{~g}$. Dengan cara yang sama didapat MTI untuk jenis ikan lainnya (Tabel 11).

Dengan demikian bila anak dengan berat badan rerata $15 \mathrm{~kg}$ mengkonsumsi daging ikan di atas sesuai dengan nilai MTI nya, maka belum berbahaya bagi kesehatan tubuh.

\section{Zincum (Zn)}

Seng (Zn) merupakan nutrien esensial manusia, sebuah kofaktor untuk lebih dari 300 enzim, dan ditemukan dalam semua jaringan. Pada manusia, konsentrasi tertinggi seng ditemukan pada tulang, otot, prostat, hati dan ginjal (EPA, 2005). Zn dalam dosis tinggi dapat berbahaya dan bersifat toksik. Absorpsi berlebih mampu menekan absorpsi Co dan Fe. Zn memiliki fungsi untuk mengkatalisis kerja enzim, memiliki peran untuk struktur protein dan membran sel, juga untuk mengatur ekspresi gen yaitu bertindak sebagai faktor transkripsi (Nurhayati et al., 2014). Myers et al., (2012) menyatakan bahwa signal seng yang tidak berfungsi berasosiasi dengan sejumlah penyakit kronis yaitu kanker, kardiovaskular, Alzheimer, dan diabetes. Seng mempunyai peranan penting dalam sintesis, sekresi, dan aksi insulin.

Dari Tabel 3 di atas dapat dilihat kadar $\mathrm{Zn}$ tertinggi dijumpai pada daging Totodi (Synodus foetens) yakni 42,55 ppm dan terendah pada daging ikan Tatameri (Gazza minuta) yakni $13,76 \mathrm{ppm}$. Data di atas menunjukkan bahwa Totodi (Synodus foetens) mengakumulasi $\mathrm{Zn}$ lebih banyak dibandingkan dengan yang lainnya. 
Seperti halnya logam berat lainnya, kadar Zn pada ikan juga terlihat bervariasi, jenis dan lokasi yang berbeda cenderung memiliki kadar $\mathrm{Zn}$ yang berbeda pula. Kadar Zn dalam ikan di Teluk Kao ini masih lebih rendah dari nilai ambang batas yang aman untuk makanan hasil laut yang ditetapkan beberapa negara kecuali Taiwan dan Tasmanian Food and-Drug dan EPA (1973) (Tabel 12).

Hasil perhitungan Maximum Weekly Intake untuk Zn disajikan pada Tabel 13. Maximum Weekly Intake adalah asupan maksimum kontaminan logam berat yang diperboleh masuk ke tubuh selama satu minggu. Dari Tabel 13 dapat dilihat kadar Zn maksimum yang diperbolehkan dikonsumsi untuk orang dewasa dengan berat $50 \mathrm{~kg}$ adalah $350 \mathrm{mg}$. Kadar tertinggi $\mathrm{Zn}$ dijumpai pada ikan Totodi (Synodus foetens) yakni 42,55 ppm atau $42,55 \mathrm{mg} / \mathrm{kg}$, artinya dalam $1 \mathrm{~kg}$ daging ikan Totodi (Synodus foetens) terdapat $42,55 \mathrm{mg} \mathrm{Zn}$.
Febrianto (2018) menyatakan konsumsi ikan orang dewasa Indonesia per orang per tahun adalah 47 $\mathrm{kg}(0,979 \mathrm{~kg}$ per minggu). Maka asupan $\mathrm{Pb}$ per minggu ke dalam tubuh adalah $(0,979: 1) \times 42,55 \mathrm{mg}=41,656$ $\mathrm{mg}$.

Kadar ini lebih rendah dari asupan maksimum per minggu (MWI) $\mathrm{Zn}$ untuk orang dewasa dengan berat badan $50 \mathrm{~kg}$ per minggu yakni $350 \mathrm{mg}$. Nilai MTI (maximum Tolerable Intake) didapat dengan membagi nilai MWI (350) mg dengan kadar Zn yang terdapat dalam 1 kg ikan yakni 42,55 mg sebagai berikut: $(350: 42,55)$ $\mathrm{x} 1 \mathrm{~kg}=8,225 \mathrm{~kg}$ atau $8255 \mathrm{~g}$ per minggu untuk orang dengan berat badan $50 \mathrm{~kg}$. Dengan cara yang sama diperoleh nilai MTI untuk ikan yang lain (Tabel 14).

Tabel 12. Perbandingan kadar $\mathrm{Zn}$ pada daging Ikan di Teluk Kao dengan kriteria dari beberapa negara

Table 12. Comparison of $\mathrm{Zn}$ in fish meat in Kao Bay with criteria of several centuries

\begin{tabular}{cc}
\hline Jenis & Kadar, ppm \\
\hline Suo (Sphyraena jello) & 21,37 \\
Gaca (Lutjanus argentimaculatus) & 41,84 \\
Totodi (Synodus foetens) & 42,55 \\
Gurara (Nemipterus japonicus) & 16,0 \\
Biji Nangka (Upeneus vittatus) & 14,64 \\
Ngafi (Stolephorus indicus) & 31,79 \\
Tatameri (Gazza minuta) & 13,76 \\
Bubara(Caranx sp) & 16,00 \\
\hline Nilai Ambang Batas & 100 \\
\hline Ditjend POM DepKes RI (Blesstino et al., 2017) & 50 \\
Bulgarian Food Codes (Peycheva et al., 2017) & 150 \\
WHO (1989)* & $30-100$ \\
FAO (1992)* & 100 \\
MFR (1985)* & 40 \\
Taiwan (Chen et al., 2001) & $4-7,28$ \\
England (Moselhy et al., 2014) & 50 \\
\hline
\end{tabular}

*Bashir et al. (2012), "***Hadinoto et al. (2014)

Tabel 13. Asupan maksimum $\mathrm{Zn}$ yang diperkenankan per minggu

Table 13. Tolerable maximum weekly intake of $\mathrm{Zn}$

\begin{tabular}{ccc}
\hline $\begin{array}{c}\text { Jenis } \\
\text { Logam }\end{array}$ & PTWI $(\mu \mathrm{g} / \mathrm{kg}$ b.b) per minggu & MW I (orang dewasa, $50 \mathrm{~kg})$ per Minggu \\
\hline $\mathrm{Zn}$ & 7000 & $350 \mathrm{mg}$ \\
$\mathrm{Zn}$ & 7000 & M W I (anak-anak, $15 \mathrm{~kg})$ per Ming \\
$105 \mathrm{mg}$
\end{tabular}

Dengan demikian bila orang dewasa dengan berat badan rerata $50 \mathrm{~kg}$ mengkonsumsi daging ikan sesuai dengan nilai MTI nya, maka belum berbahaya bagi kesehatan tubuh.
Dari Tabel $13 \mathrm{di}$ atas dapat dilihat kadar $\mathrm{Zn}$ maksimum yang diperbolehkan dikonsumsi untuk anak dengan berat badan $15 \mathrm{~kg}$ adalah $105 \mathrm{mg}$. Kadar tertinggi Zn dijumpai pada ikan Totodi (Synodus 
foetens) yakni $42,55 \mathrm{ppm}$ atau $42,55 \mathrm{mg} / \mathrm{kg}$, artinya dalam $1 \mathrm{~kg}$ daging ikan Totodi terdapat 42,55 $\mathrm{mg} \mathrm{Zn}$. Bila konsumsi ikan anak-anak dengan berat badan 15 kg rerata per minggu sepertiganya orang dewasa yakni $0,326 \mathrm{~kg}$, maka asupan $\mathrm{Pb}$ nya ke dalam tubuh adalah $(0,326: 1) \times 42,55 \mathrm{mg}=13,871 \mathrm{mg}$.

Kadar ini lebih rendah dari MWI Zn untuk anakanak dengan berat badan $15 \mathrm{~kg}$ per minggu yakni 105 mg.
Nilai MTI (maximum Tolerable Intake) didapat dengan membagi nilai MWI (105) mg dengan kadar Zn yang terdapat dalam $1 \mathrm{~kg}$ ikan yakni $42,55 \mathrm{mg}$ sebagai berikut: $(105: 42,55)$ x $1 \mathrm{~kg}=2,467 \mathrm{~kg}$ atau $2467 \mathrm{~g}$ per minggu untuk orang dengan berat badan $15 \mathrm{~kg}$. Dengan cara yang sama diperoleh nilai MTI untuk ikan yang lain (Tabel 15). Dengan demikian bila anak dengan berat badan rerata $15 \mathrm{~kg}$ mengkonsumsi daging ikan dan kerang di atas sesuai dengan nilai MTI nya, maka belum berbahaya bagi kesehatan tubuh.

Tabel 14. Asupan maksimum $\mathrm{Zn}$ per minggu yang diperbolehkan untuk orang dewasa dengan berat badan $50 \mathrm{~kg}$ Table 14. Tolerable maximum weekly Intake of Zn for adults with $50 \mathrm{~kg}$ bodyweight

\begin{tabular}{lcc}
\hline \multicolumn{1}{c}{ Jenis Ikan } & Zn, $\mathrm{mg} / \mathrm{kg}=\mathrm{Ct}$ & $\mathrm{MTI}=\mathrm{MWI} / \mathrm{Ct}(\mathrm{g}), \mathrm{MWI}$ Zn: 350 mg \\
\hline Suo (Sphyraena jello) & 21,37 & 16378 \\
Kaca (Lutjanus argentimaculatus) & 41,84 & 8365 \\
Totodi (Synodus foetens) & 42,55 & 8255 \\
Gurara (Nemipterus japonicus) & 16,0 & 21875 \\
Biji Nangka (Upeneus vittatus) & 14,64 & 23907 \\
Ngafi (Stolephorus indicus) & 31,79 & 11009 \\
Tatameri (Gazza minuta) & 13,76 & 25436 \\
Bubara(Caranx $\mathrm{sp}$ ) & 16,00 & 21875 \\
\hline
\end{tabular}

Tabel 15. Asupan maksimum Zn per minggu yang diperbolehkan untuk anak dengan berat badan $15 \mathrm{~kg}$ Table 15. Tolerable maximumweekly intake of $\mathrm{Zn}$ for childrem with $15 \mathrm{~kg}$ body weight

\begin{tabular}{lcc}
\hline \multicolumn{1}{c}{ Jenis Ikan } & Zn, $\mathrm{mg} / \mathrm{kg}=\mathrm{Ct}$ & $\mathrm{MTI}=\mathrm{MWI} / \mathrm{Ct}(\mathrm{g})$, MWI Zn: 105 mg \\
\hline Suo (Sphyraena jello) & 21,37 & 4913 \\
Kaca (Lutjanus argentimaculatus) & 41,84 & 2509 \\
Totodi (Synodus foetens) & 42,55 & 2647 \\
Gurara (Nemipterus japonicus) & 16,0 & 6562 \\
Biji Nangka (Upeneus vittatus) & 14,64 & 7172 \\
Ngafi (Stolephorus indicus) & 31,79 & 3302 \\
Tatameri (Gazza minuta) & 13,76 & 7630 \\
Bubara(Caranx $\mathrm{sp})$ & 16,00 & 6562 \\
\hline
\end{tabular}

\section{Nikel}

Nikel (Ni) adalah logam esensial dan biasanya terdapat di lingkungan pada kadar yyang sangat kecil. Namun belum ada laporan dampak kekurangan Ni pada manusia (Barceloux, 1999). Ni diketahui bersifat karsinogenik (Salnikow et al., 2005) . Selain itu, fibrosis, tumor, radang paru-paru dan emfisema terjadi juga disebabkan oleh Ni (Forti et al., 2011).

Dari Tabel 3 di atas dapat dilihat kadar Ni dalam daging ikan tertinggi dijumpai dalam daging ikan tatameri (Gazza minuta) yakni 1,18 ppm dan terendah dalam daging gaca (Lutjanus argentimaculatus) yakni $0,28 \mathrm{ppm}$. Data ini menunjukkan bahwa ikan tatameri (Gazza minuta) mengakumulasi Ni lebih tinggi dibandingkan dengan ikan lainnya. Kadar Ni pada ikan di atas juga bervariasi sesuai dengan jenis.
Pada Tabel 16 berikut dapat dilihat perbandingan kadar Ni pada ikan di Teluk Kao dengan baku mutu dari beberapa negara. Dari tabel tersebut terlihat kadar Ni dalam ikan di Teluk Kao ini masih lebih rendah dari nilai ambang batas yang aman untuk makanan hasil laut yang ditetapkan beberapa negara. Hasil perhitungan Maximum Weekly Intake untuk $\mathrm{Ni}$ disajikan pada Tabel 17. Dari tabel di atas dapat dilihat kadar Ni maksimum yang diperbolehkan dikonsumsi untuk orang dewasa dengan berat $50 \mathrm{~kg}$ berturut-turut adalah $1,75 \mathrm{mg}$. Kadar tertinggi Ni dijumpai pada ikan tatameri (Gazza minuta) yakni $1,18 \mathrm{ppm}$ atau $1,18 \mathrm{mg} /$ $\mathrm{kg}$, artinya dalam $1 \mathrm{~kg}$ daging ikan tatameri (Gazza minuta) terdapat $1,18 \mathrm{mg} \mathrm{Ni}$. Konsumsi ikan orang dewasa Indonesia per orang per tahun adalah $47 \mathrm{~kg}$ $(0,979 \mathrm{~kg}$ per minggu). Maka asupan Ni per minggu ke dalam tubuh adalah $(0,979: 1) \times 1,18 \mathrm{mg}=1,155 \mathrm{mg}$. 
Kadar ini lebih rendah dari MWI Ni untuk orang dewasa dengan berat badan $50 \mathrm{~kg}$ per minggu yakni $1,75 \mathrm{mg}$. Nilai $1,75 \mathrm{mg}$ ini hanya akan tercapai apabila orang memakan daging tatameri (Gazza minuta) sebanyak $(1,75: 1,18) \times 1 \mathrm{~kg}=1,483 \mathrm{~kg}$ atau $1483 \mathrm{~g}$ per minggu untuk orang dengan berat badan $50 \mathrm{~kg}$. Pada tabel berikut dapat dilihat Maximum Tolerable Intake (MTI) untuk masing-masing ikan (Tabel 18). Dengan demikian bila orang dewasa dengan berat badan rerata $50 \mathrm{~kg}$ mengkonsumsi daging ikan di atas sesuai dengan nilai MTI nya, maka belum berbahaya bagi kesehatan tubuh.

Dari Tabel 17 dapat dilihat kadar Ni yang diperbolehkan dikonsumsi untuk anak dengan berat badan $15 \mathrm{~kg}$ adalah 0,525 mg. Kadar Ni tertinggi pada ikan dijumpai pada ikan tatameri yakni $1,18 \mathrm{ppm}$ atau $1,18 \mathrm{mg}$ per $\mathrm{kg}$, artinya dalam $1 \mathrm{~kg}$ daging ikan tatameri terdapat $1,18 \mathrm{mg} \mathrm{Ni}$. Kadar $\mathrm{Ni}$ yang diperkenankan masuk per minggu ke tubuh anak dengan berat badan $15 \mathrm{~kg}$ adalah 0,525 mg. Kadar ini akan tercapai bila anak mengkonsumsi daging ikan tatameri sebanyak $(0,525: 1,18) \times 1 \mathrm{~kg}=0,4449 \mathrm{~kg}$ atau $444 \mathrm{~g}$. Bila konsumsi anak sepertiganya orang dewasa yakni $0,326 \mathrm{~kg}$, maka asupan $\mathrm{Ni}$ ke tubuhnya adalah $(0,326: 1) \times 1,18 \mathrm{mg}=0,384 \mathrm{mg}$. Kadar ini lebih rendah dari kadar yang diperbolehkan untuk anak dengan berat badan $15 \mathrm{~kg}$ yakni 0,525 mg. Nilai 0,525 mg ini akan diperoleh bila anak mengkonsumsi ikan sebanyak $(0,525: 1,18) \times 1 \mathrm{~kg}=444,915 \mathrm{~g}$. Dengan cara yang sama didapat MTI untuk jenis ikan lainnya (Tabel 18).

Dengan demikian bila anak dengan berat badan rerata $15 \mathrm{~kg}$ mengkonsumsi daging ikan dan kerang di atas sesuai dengan nilai MTI nya, maka belum berbahaya bagi kesehatan tubuh.

Tabel 16. Perbandingan kadar Ni pada daging Ikan di Teluk Kao dengan kriteria dari beberapa negara

Table 16. Comparasion of Ni concentration in meat fishes in Kao Bay with criteria of several countries

\begin{tabular}{lc}
\hline \multicolumn{1}{c}{ Jenis } & Kadar, ppm \\
\hline Suo (Sphyraena jello) & 0,08 \\
Gaca (Lutjanus argentimaculatus) & 0,28 \\
Totodi (Synodus foetens) & 0,49 \\
Gurara (Nemipterus japonicus) & 0,09 \\
Biji Nangka (Upeneus vittatus) & 0,28 \\
Ngafi (Stolephorus indicus) & 0,09 \\
Tatameri (Gazza minuta) & 0,28 \\
Bubara(Caranx sp) & 0,08 \\
\hline \multicolumn{1}{c}{ Nilai Ambang Batas } \\
\hline Bulgharian Food Codex (Peycheva et al., 2016) & 0,5 \\
USFDA (Javed et al., 2013) & 70 \\
WHO (1989 dalam Kumar et al., 2012) & $0,5-1,0$ \\
FAO/WHO (1984, 2011 dalam Shovon et al., 2017) & 80 \\
Canadian Food Standard (Papagiannis et al., 2004) & 1,0 \\
\hline
\end{tabular}

Tabel 17. Asupan maksimum Ni yang diperkenankan per minggu

Table 17. Tolerable maximum weekly intake of $\mathrm{Ni}$

\begin{tabular}{ccc}
\hline $\begin{array}{c}\text { Jenis } \\
\text { Logam }\end{array}$ & PTWI $(\mu \mathrm{g} / \mathrm{kg}$ b.b) per minggu & MWI (orang dewasa, $50 \mathrm{~kg}$ ) per Minggu \\
\hline $\mathrm{Ni}$ & 35 & $1,75 \mathrm{mg}$ \\
& & MWI (anak-anak, $15 \mathrm{~kg})$ per Minggu \\
$\mathrm{Ni}$ & 35 & $0,525 \mathrm{mg}$ \\
\hline
\end{tabular}


Tabel 18. Asupan maksimum Ni per minggu yang diperbolehkan untuk orang dewasa dengan berat badan $50 \mathrm{~kg}$ Table 18. Tolerable maximum weekly Intake of $\mathrm{Ni}$ for adults with 50 body weight

\begin{tabular}{lcc}
\hline \multicolumn{1}{c}{ Jenis Ikan } & $\mathrm{Ni}, \mathrm{mg} / \mathrm{kg}=\mathrm{Ct}$ & $\mathrm{MTI}=\mathrm{MWI} / \mathrm{Ct}(\mathrm{g}), \mathrm{MWI}$ Ni: $1,75 \mathrm{mg}$ \\
\hline Suo (Sphyraena jello) & 0,33 & 5303 \\
Kaca (Lutjanus argentimaculatus) & 0,28 & 6250 \\
Totodi (Synodus foetens) & 0,60 & 2916 \\
Gurara (Nemipterus japonicus) & 0,47 & 3723 \\
Biji Nangka (Upeneus vittatus) & 0,83 & 2108 \\
Ngafi (Stolephorus indicus) & 0,81 & 2160 \\
Tatameri (Gazza minuta) & 1,18 & 1483 \\
Bubara(Caranx sp) & 1,13 & 1548 \\
\hline
\end{tabular}

Tabel 19. Asupan maksimum Ni per minggu yang diperbolehkan untuk anak dengan berat badan $15 \mathrm{~kg}$ Table 19. Tolerable maximum weekly intake of $\mathrm{Ni}$ for children with $15 \mathrm{~kg}$ body weight

\begin{tabular}{lcc}
\hline \multicolumn{1}{c}{ Jenis Ikan } & $\mathrm{Ni}, \mathrm{mg} / \mathrm{kg}=\mathrm{Ct}$ & $\mathrm{MTI}=\mathrm{MWI} / \mathrm{Ct}(\mathrm{g}), \mathrm{MWI}$ Ni: 0,525 mg \\
\hline Suo (Sphyraena jello) & 0,33 & 1590 \\
Kaca (Lutjanus argentimaculatus) & 0,28 & 1875 \\
Totodi (Synodus foetens) & 0,60 & 875 \\
Gurara (Nemipterus japonicus) & 0,47 & 1117 \\
Biji Nangka (Upeneus vittatus) & 0,83 & 632 \\
Ngafi (Stolephorus indicus) & 0,81 & 648,148 \\
Tatameri (Gazza minuta) & 1,18 & 444 \\
Bubara(Caranx sp) & 1,13 & 464 \\
\hline
\end{tabular}

Hasil penelitian ini menunjukkan adanya perbedaan kadar $\mathrm{Pb}, \mathrm{Cd}, \mathrm{Zn}$ dan $\mathrm{Ni}$ dalam setiap jenis ikan. Perbedaan kadar ini dapat disebabkan oleh perbedaan lingkungan perairan pada saat penelitian, jenis spesies dan kelamin, panjang, berat, dan umur ikan (Nady et al., 1984)(Grieb et al., 1990)(Ahmad et al., 2015). Pola akumulasi logam berat dalam tubuh organisme laut tidak hanya dipengaruhi oleh ukuran tubuh saja, faktor eksternal seperti pilihan makanan dan faktor internal seperti kecepatan metabolisme juga mempengaruhi akumulasi logam berat (Louma et al., 2008). Faktor makanan pada ikan laut sangat menentukan akumulasi logam berat dalam daging (Velusamy et al., 2016).

Ikan yang terpapar senyawa beracun namun tidak mati, organ tubuhnya dapat mengalami kerusakan jaringan. Resiko yang dapat terjadi antara lain adalah ikan tidak menghasilkan keturunan dan walaupun menghasilkan keturunan akan mengalami cacat fisik, misalnya pergerakannya tidak normal/disorientasi. Logam berat yang masuk melalui makan, selanjutnya akan didistribusikan oleh darah ke organ-organ tubuh lainnya seperti daging dan tulang dan ada pula yang masuk ke dalam hati untuk kemudian diekskresikan (Houser et al., 2012).

Kiranya hal-hal tersebut di ataslah yang menyebabkan adanya perbedaan kadar logam berat pada setiap jenis ikan yang hidup di Teluk Kao.

\section{KESIMPULAN}

Kadar $\mathrm{Pb}, \mathrm{Cd}, \mathrm{Zn}$ dan $\mathrm{Ni}$ pada ikan masih sesuai dengan nilai ambang batas yang ditetap oleh beberapa negara sehingga belum berbahaya bila dikonsumsi, asal sesuai dengan MTI nya.

\section{UCAPAN TERIMA KASIH}

Penulis menyampaikan ucapan terima kasih kepada Kepala Badan Penelitian dan Pengembangan Daerah, Provinsi Maluku Utara (2015), yang telah memberikan dana dalam penelitian ini. Ucapan terima kasih yang sedalam-dalamnya juga di sampaikan kepada Bp. Fasmi Ahmad. S.Pi (alm) mantan Kepala Stasiun Penelitian P2O-LIPI Ternate dan Prof. Dr. Muhajir. MSi dari Fakultas Perikanan dan Ilmu Kelautan UNHAIR yang telah banyak berpartisipasi dalam penelitian ini.

\section{DAFTAR PUSTAKA}

Ahmad, I.N., Noh, M.F.M., Mahiyuddin, W.R.W., H. Jaafar, H., Ishak, I., Azmi, W.N.F.W., Veloo, Y., \& Hairi, M.H. (2015). Mercury Levels in marine Fish Commonly Consumed in Penensular Malaysia. Enviro Sci Pollut Res Int; 22(5): 3672-3686.

Agustina, T. (2010). Kontaminasi Logam Berat Pada Makanan dan Dampaknya pada Kesehatan. Teknubuga, 2 (2): hal. 53-65.

Barceloux, D. G. (1999). Nickel. Clin. Toxicol. 37: 239. 
Bashir, A.F., Othman, M.S., \& Mazlan, A.G. (2012). Evaluation of Trace Metal Levels in Tissues of Two Commercial Fish Species in Kapar and Mersing Coastal Waters, Peninsular Malaysia. Hindawi Publishing Corporation Journal of Environmental and Public Health Volume 2012, Article ID 352309, 10 pages.

Blesstino, G.A., Maddusa, S.S., \& Joseph, W.B.S.J. (2017). Analisis Kandungan (Zn) dalam Air, Sedimen, Kerang dan Ikan di Sungai Tondano Tahun 2017 . Makalah: Fakultas Kesehatan Masyarakat Universitas Sam Ratulangi: 8 hal.

Cahyani, N., Batu, DTFL., \& Sulistiono. (2016). Kandungan Logam Berat Pb, Hg, Cd dan Cu Pada Daging Ikan Rejung (Silago sihama) di Estuari Sungai Donan, Cilacap, Jawa Tengah.JPHPI, Vol 19 No 5: 267-276.

Chen, C.T., \& Chen, M.H. (2001). Heavy Metal Concentrations in Nine Species of Fishes Caught in Coastal Waters off Ann-Ping, S.W. Taiwan. Journal of Food and Drug Analysis, Vol. 9, No. 2, Pages 107-114

Dewi. (2011). Analisis Cemaran Logam Timbal (Pb), Tembaga (Cu), dan Kadmium (Cd) Dalam Tepung Gandum Secara Spektrofotometri Serapan Atom. Skripsi. Jakarta: FMIPA Program Studi Farmasi Universitas Indonesia.

Duruibe, J.O., Ogwuegbu, M.C., \& Egwurugwu, J.N. (2007). Heavy Metal Pollution and Human Biotoxic Effects. International Journal of Physical Sciences, (2), 112-118.

Edward. (2017). Prediksi Kualitas Sedimen di Teluk Koa, Halmahera dengan Pendekatan Analisis Indeks. Prosiding Semnaskan UGM XV, Jogyakarta: 252- 261.

EPA (Environmental Protection Agency). (2005). Toxicological Review of Zinc and Compound. Washington (US) : Environmental Protection Agency.

Febrianto. F. (2018). Kondisi Terumbu Karang Indonesia Jelek, KKP: Segera Kami Pulihkan. Reporter: Fajar Febrianto, Editor: Kodrat Setiawan. Minggu, 3 Juni 2018 13: 44 WIB (https://bisnis. tempo.co/ read/1094997/kkp-konsumsi-ikan-ditargetkan-508-kg-per-kapita-pa-pa-2018).

Forti, E., Salovaara, S., Cetin, Y., Bulgheroni, A., Tessadri, R., Jennings, P., \& Prieto, P. (2011). In Vitro Evaluation of the Toxicity Induced by Nickel Soluble and Particulate Forms in Human Air way Epithelial Cells. Toxicology in Vitro. 25(2): 454461.

Grieb, M.T., Driscoll, C.T., Gloss, S.V., Schofield, C.L., Bowie, G.L., \& Porcella, D.B. (1990). Factor Affecting Mercury Accumulation in Fish in The Upper Michigan Peninsula. Environmental Toxico- logy and Chemistry, Vol 9: 919-930.

Hutagalung, H., Riyono, S.H., \& Setiapermana, D. (1997). Metode Analisis Air Laut, Sedimen, dan Biota. Buku 2. Pusat Penelitian dan Pengembangan Oseanologi. LIPI. $81 \mathrm{hlm}$.

Hauser-Davis, R.A., Bastos, F.F., de Oliveira, T. F., Ziolli, R.L., \& de Campos, R.C. (2012). Fish bile as a biomarker for metal exposure. Marine Pollution Bulletin, (64): 1589-1595.

Hidayah, A.M., Purwanto, M.A., \& Soeprobowati, T.R. (2014). Biokonsentrasi Faktor Logam Berat Pb, $\mathrm{Cd}, \mathrm{Cr}$ dan $\mathrm{Cu}$ pada Ikan Nila (Oreochromis niloticus Linn.) di Karamba Danau Rawa Pening. BIOMA Vol. 16, No. 1, Hal. 1-9.

Hashim, R., Song, T.H., Muslim, N.Z Md \& Yen, T.P. (2014). Determination of Heavy Metal Levels in Fishes from the Lower Reach of the Kelantan River, Kelantan, Malaysia Tropical Life Sciences Research, 25(2), 21-39.

Hadinoto, S., \& Dewi, N.M.S. (2014). Analisis kandungan logam berat dari beberapa jenis ikan hasil budidaya kerambah sebagai sumber olahan pangan. Majalah Biam Vol. 10, No. 1, Hal. 8-15.

Javed., Mehjbeen., \& Usmani, N. (2013). Assessment of heavy metal $(\mathrm{Cu}, \mathrm{Ni}, \mathrm{Fe}, \mathrm{Co}, \mathrm{Mn}, \mathrm{Cr}, \mathrm{Zn})$ pollution in effluent dominated rivulet water and their effect on glycogen metabolism and histology of Mastacembelus armatus Springer Plus 2013(2): 390.

Kumar, B., Sajwan, K. S., \& Mukherjee, D. P. (2012). Distribution of Heavy Metals in Valuable Coastal Fishes from North East Coast of India. Turkish Journal of Fisheries and Aquatic Sciences (12): 81 88.

Kuras, R., Wasowicz, W., \& Janasik, B. (2017). Assessment of Mercury Intake from Fish Meals Based on Intervention Research in the Polish Subpopulation. Biol Trace Elem Res (179): 23-31.

Lihan, T., Ismail, N., Mustapha, M.A., \& Rahim, S.A. (2006). Kandungan Logam Berat dalam Makanan Laut dan Kadar Pengambilannya oleh Penduduk di Tanjung Karang, Selangor. The Malaysian Journal of Analytical Sciences Vol 10 No 2 : 197-204.

Luoma, S. N., \&. Rainbow, P.S. (2008). Metal contamination in aquatic environment: science and lateral management. Cambridge Universi- ty Press : $126 \mathrm{p}$.

Myers, S.A., Nield, A., \& Myers, M. (2012). Zinc transporters, mechanisms of action and therapeutic utility: implications for type 2 diabetes mellitus. Journal of Nutrition and Metabolism, Volume 2012:1-13. doi:10.1155/2012/173712.

Moselhy-El. M.Kh., Othman, A.I., El-Azem, H. Abd., \& El-Metwally, M.E.A. (2014). Bioaccumulation of 
heavy metals in some tissues of ûsh in the Red Sea, Egypt. Egyptian Journal of Basic and Applied Science I: 97-105.

Nady-El Sayed-El, P. (1984). Bioaccumula tion of Mercury in Some Coastal Marine Fishes from Alexandria Waters. Paper presented at FAO/ UNEP/WHO /IOC/IAEA Meeting in The Biochemical Cycle of Mercury in The Mediterranean. Siena, Italy 27-31 August 1984. FAO. Fish. Report (325) Suppl: 187 p.

Nurhayati T., Nurjanah., \& Zamzami, A.H. (2014). Komposisi mineral mikro dan logam berat pada ikan bandeng dari tambak Tanjung Pasir Kabupaten Tangerang. Depik, 3(3): 234-240.

Papagiannis, I., Kagalou, I., Leonardos, J., Petridis, D., \& Kalfakakou, V. (2004). Copper and zinc in four freshwater fish species from Lake Pamvotis (Greece). Environ. Int., 30: 357-362.

Purnomo, T., \& Muchyiddin. (2016). Analisis Kandungan Timbal $(\mathrm{Pb})$ pada Ikan Bandeng (Chanos chanos Forsk.) di Tambak Kecamatan Gresik. Neptunus, Vol. 14, No. $1: 68-77$.

Peycheva, K., Panayotova, V., \& Stancheva, M. (2016). Assessment of human health risk for copper, arsenic, zinc, nickel, and mercury in marine fish species collected from Bulgarian black sea coast. Int Jour of Fisheries and Aquatic Studies; 4(5): 41-46.

Salnikow, K., \& Kasprzak, K. S. (2005). Ascorbate Depletion: A Critical Step in Nickel Carcinogenesis? Environ- mental Health Perspectives. 113(5): 577-584.
Shovon, M.N.H., Majumdar, B.C., \& Rahman Z. (2017). Heavy Metals (Lead, Cadmium and Nickel) Concentration in Different Organs of Three Commonly Consumed Fishes in Bangladesh. Fisheries and Aqua culture. Fish Aqua J, an open access journal. $5 \mathrm{p}$.

SNI (Standar Nasional Indonesia). 2009. Batas Maksimum Cemaran Logam Berat dalam pangan : 25 hal.

Suyanto, A., Kusmiyati, S., Retnaningsih, Ch. (2010). Residu Logam Berat Ikan dari Perairan Tercemar di Pantai Utara Jawa Tengah (Residual Heavy Metals in Fish from Contaminated Water in North Coast of Central Java) Jurnal Pangan dan Gizi Vol 01 No. 02 :1-9.

Turkmen, M., Turkmen, A., \& Tepe, Y. (2008). Metal contaminations in five species from, Marmara, Aegean, and Mediteranean Sea. Turkey. Journal Chil Chem Soc 53 (1): 1435-1439.

Velusamy, A., Kumar, P.S., Ram, A., \& Chinnadurai, S. (2016). Bioaccumu-lation of heavy metals in commercially important marine fishes from Mumbay Harbor, India. Marine Pollution Bulletin, 81: 218224.

Widaningrum., Miskiyah., \& Suismono. (2007). Bahaya Kontaminasi Logam Berat dalam Sayuran dan Alternatif Pencegahan Cemarannya. Balai Besar Penelitian dan Pengembangan Pascapanen Pertanian. Buletin Teknologi Pascapanen Pertanian (3): hal. 16-27. 